\title{
KAJIAN PERBAIKAN PENGELOLAAN SAMPAH KOTA PALANGKA RAYA DALAM PERSPEKTI PRAKTIS DAN PENDIDIKAN
}

\author{
Research on improving the waste management of Palangka Raya City \\ in a practical and educational perspective
}

\section{Muhamad Yusuf*}

Universitas Muhammadiyah

Palangkaraya, Palangka Raya, Central

Kalimantan, Indonesia

email:

yusuf.quratayun@gmail.com

\section{Kata Kunci: \\ Kajian \\ Pengelolaan}

Sampah

Keywords:

\section{Accepted}

June 2015

\section{Published}

Oktober 2015

\begin{abstract}
Abstrak
Penelitian ini bertujuan untuk mengkaji sistem pengelolaan sampah di Kota Palangka Raya dan memetakan sistem pembagian wilayah pelayanan dan sistem pengumpulannya dan sosialisasi model pengelolaan sampah dan Focus Group Discussion (FGD) pada lingkungan sekolah di masyarakat kota Palangka Raya. Dalam penelitian ini menggunakan deskriftif kualitatif. Data yang dikumpulkan, disusun sedemikian rupa disesuaikan dengan kebutuhan analisis. Data yang dikumpulkan terdiri dari data sekunder dan data primer. Data sekunder yang dikumpulkan dari instalasi terkait, sedangkan pengumpulan data primer dilaksanakan dengan metode survey. Untuk keperluan data dan informasi yang bersifat makro spesial digunakan pendekatan Rapid Rural Appraisal (RRA), sedangkan data yang bersifat mikro digunakan wawancara mendalam (Deep Intervier) dengan menggunakan kuesioner.
\end{abstract}

Hasil penelitian yang dilakukan, terdapat peningkatan pengelolaan persampahan dalam skala Kota Palangka Raya. Terkait dengan perlunya menyempurnakan struktur organisasi pengelolaan yang bersifat terpadu dan lintas sektoral agar terjadi peningkatan partisipasi masyarakat dan peningkatan pelayanan.

\begin{abstract}
This research aims to study the waste management system in Palangka Raya City and map the system of Division of Service territory and its collection system and socialization of the garbage management and Focus Group Discussion (FGD) model in the environment School in the community of Palangka Raya. In this study use qualitative deskriftif. The Data collected, arranged in a manner tailored to the needs of analysis. The data collected consists of secondary data and primary data. Secondary data collected from related installations, while the primary data collection is implemented by survey method. For the purposes of data and information that is macro-special is used Rapid Rural Appraisal (RRA) approach, while micro-data is used in-depth interviews (Deep Interview) using questionnaires.
\end{abstract}

The results of the research conducted, there is an improvement in the management of the city scale Palangka Raya. In relation to the need to improve the organizational structure of management that is integrated and cross-sectoral to increase community participation and improvement of service.

\section{PENDAHULUAN}

Sampah merupakan limbah yang dihasilkan dari adanya aktivitas manusia. Jumlah atau volume sampah sebanding dengan tingkat konsumsi manusia terhadap barang atau material yang gunakan sehari-hari, sehingga pengelolaan sampah tidak terlepas dari pengelolaan gaya hidup masyarakat. Sampai saat ini permasalahan sampah belum tertangani dengan baik terutama di perkotaan. Sampah telah menjadi permasalahan nasional sehingga pengelolaannya perlu dilakukan secara komprehensif dan terpadu dari hulu sampai ke hilir agar dapat memberikan manfaat secara ekonomi, sehat bagi masyarakat, aman bagi lingkungan, serta dapat mengubah perilaku masyarakat.

Peningkatan produksi sampah telah menimbulkan masalah pada lingkungan seiring dengan peningkatan jumlah penduduk perkotaan. Sementara, lahan tempat pembuangan akhir (TPA) sampah juga makin terbatas. Kondisi ini makin memburuk manakala pengelolaan sampah di masing-masing daerah masih kurang efektif, 
efisien, dan berwawasan lingkungan serta tidak terkoordinasi dengan baik.

Sudradjat (2008) menyatakan bahwa permasalahan sampah dapat dikatakan sebagai masalah kultural karena dampaknya mengena pada berbagai sisi kehidupan terutama di kota besar seperti Jakarta, Semarang, Surabaya, Bandung, Palembang, dan Medan. Permasalahan pengelolaan persampahan perkotaan saat ini merupakan akibat dari berbagai perubahan yang cepat, dalam hal tatanan 2 kehidupan sosial, ekonomi, politik, dan budaya. Perubahan yang cepat itu mengakibatkan beban TPA sampah menjadi semakin berat.

Selama ini sampah menjadi permasalahan yang sulit ditangani karena setiap hari dari berbagai aspek akan menghasilkan bahan-bahan yang sudah tidak dikehendaki disebut sampah, terutama sampah rumah tangga dan sampah industri. Sedangkan pembusukannya membutuhkan waktu yang cukup lama. Hal ini akan menjadikan penumpukan sampah.

Pengelolaan sampah di kota Palangka Raya sudah cukup baik walaupun belum maksimal. Sampah dari rumah tangga, kantor, sekolah, pasar dan tempat umum lainnya yang merupakan gabungan anatara sampah organic dan anorganik diakumulasi, dijadikan satu, selanjutnya dibuang ketempat pembuangan sementara (TPSS), selanjutnya dari TPSS diangkut oleh truk sampah ke tempat pembuangan sampah akhir (TPA) yang jaraknya cukup jauh dari pusat kota sampah domestic bagi penduduk yang bermukim di tepi kanal dan saluran air dibuang begitu saja ke badan air tersebut layaknya tong sampah. Di TPA, sampah ditumpuk (open dumping) dan dibiarkan mengalami pembusukan (khusus sampah organik), sementara anorganik seperti botol, kaleng, potongan kayu, bahan bangunan, besi dan lainnya adalah masih tanda tanya apakah akan diolah atau tidak. Sementara pemanfaatannya secara ekonomi oleh masyarakat dilakukan melalui tangan para pemulung yang memisahkan item sampah dari akumulasi organik dan anorganik. Kondisi para pemulung ini rentan tererang penyakit karena sampah dan TPSs maupun TPA sangat tidak bersih dan higenis.

Dari sekilas gambaran penanganan sampah di Kota Palangka Raya tersebut, pemisahan atau separasi sampah belum menjadi budaya oleh kebanyakan penduduk/masyarakat di Kota Palangka Raya, dan membuang sampah sembarangan di tempat umum merupakan kebiasaan seperti juga halnya membuang sampah di badan air (sungai, kanal, saluran, air, danau, dan rawa). Pembuangan sampah yang baik umumnya meliputi pemisahan secara seksam sampah pada tingkat individu, selanjutnya melakukan pembuangan sampah ke tempat sampah (tong sampah) selanjutnya ke TPS dan TPA.

Tenaga dan biaya pengelolaan (pemerintah) tentunya akan banyak dihabiskan jika pengelolaan sampah misalnya dillakukan dengan mengadakan/mengimpor mesin-mesin pemisah sampah. Disisi lain jika pengelolaan sampah ditekan pada teknis pemisahan sampah yang dilakukan pada tingkat individu, hal ini diperkirakan akan menghemat biaya lebih dari $50 \%$, tentunya lebih menguntungkan secara ekonomi dan ekologi. Walaupun teknik pemisahan secara individu mungkin hasilnya lebih dapat terlihat dalam jangka panjang, tetapi ini adalah cara terbaik karena mengandung unsur pendidikan dan akan merubah budaya membuang sampah secara sembarangan oleh masyarakat.

\section{METODOLOGI}

Data yang dikumpulkan, disusun sedemikian rupa disesuaikan dengan kebutuhan analisis. Data yang dikumpulkan terdiri dari data sekunder dan data primer. Data sekunder yang dikumpulkan dari instalasi terkait, sedangkan pengumpulan data primer dilaksanakan dengan metode survey. Untuk keperluan 
data dan informasi yang bersifat makro spesial digunakan pendekatan Rapid Rural Appraisal (RRA), sedangkan data yang bersifat mikro digunakan wawancara mendalam (Deep Intervier) dengan menggunakan kuesioner.

Lokasi kegiatan sistem pengelolaan sampah dan memetakan sistem pembagian wilayah pelayanan dan sistem pengumpulan di Kota Palangka Raya meliputi Kecamatan Jekan Raya, Pahandut, Bukit Batu, Rakumpit, dan Sabangau. Sedangkan kegiatan sosialisasi pada sekolah dan masyarakat dilakukan di Kecamatan Jekan Raya dan Kecamatan Pahandut Kota Palangka Raya.

\section{HASIL DAN PEMBAHASAN}

Berdasarkan hasil penelitian dilapangan tentang Kajian Praktis Pengelolaan Sampah Kota Palangka Raya dalam Perspektif Praktis dan Pendidikan yaitu :

I. Kegiatan pemerintah kota Palangka Raya yang meniti beratnya beberapa teknologi dalam upaya pengelolaan sampah sesuai dengan krakteristik sampah dan kemampuan sumberdaya daerah setempat dalam mengatasi dari berbagai jenis sampah sesuai dengan karakteristik sampah sangatlah minim. Pengelolaan sampah di Palangka Raya selama ini ditangani oleh Dinas Pasar dan Kebersihan untuk menangani timbunan sampah yang berasal dari lingkungan aktivitas masyrakat masih menitik beratkan pada pendekatan akhir yaitu sampah dikumpulkan diangkut dan dibuang ketempat pemrosesan akhir (TPA) dan diupayakan melalui pengurangan dari sumbernya.

2. Kebijakan, Peraturan dan Pengelolaan

Secara umum satuan kerja perangkat daerah (SKPD) yang mengelola masalah persampahan adalah Dinas Pasar dan Kebersihan serta Badan Lingkungan Hidup. Program satuan kerja perangkat daerah kedua institute tersebut dalam
Rencana Pembangunan Jangka Menengah Tahap ke I Tahun 2008-2013.

Faktor penghambat peraturan daerah Kota Palangka Raya Nomor 3 Tahun 2006 Tentang pengelolaan Kebersihan lingkungan dan pertamanan berupa kinerja petugas lapangan yang tidak konsisten, koordinasi tim terpadu lebih menonjolkan ego sektoral, anggaran tiap tahun mengalami pengurangan,kurangnya kesadaran warga, dan adanya perpindahan PNS Profesional. Faktor pendorong implementasi kebijakan berupa terbitnya peraturan perudangundangan,pengelolaan sampah dari cost menjadi profil menjadi dasar bagi pola kemitraan masyarakat pemerintah dan privat sektor, sementara adanya sikap pelaksana menujang walaupun dengan upah yang minim.

3. Persepsi Masyarakat

Identifikasi terhadap persepsi masyarakat mengenai tempat pembuangan sampah sementara (TPS) Di kota Palangka Raya merupakan salah satu unsure penting dalam studi ini. Untuk mengungkap persepsi masyarakat terhadap permasalahan keberadaan TPS tersebut setelah dilakukan survey lapangan dengan mengambil sampel masyarakat. Pengambilan sampel tersebut dengan mempertimbangkan bahwa masyarakat merupakan komunitas yang paling intensif berinteraksi dengan kawasan sekitarnya.

4. Focus Grup Discussion (FGD)

Kegiatan FGD dengan masyarakat dilakukan di dua tempat yaitu kecamatan pahandut dan kecematan jekan raya, dipilihnya dua kecamatan dikarenakan dua wilayah tersebut merupakan penghasil sampah terbesar dan memiliki pendudukan terbanyak Kota Palangka Raya. Beberapa pertanyaan secara umum yang disampaikan peserta FGD adalah sebagai berikut :

a. Bagaimana Pengumpulan Sampah dari rumah hingga TPS 
b. Bagaimana sebaiknya penempatan TPS Lokasi pemisah dan ukurannya

c. Kapan waktu pengambilan dan pengumpulan sampah

d. Bagaimana sebaiknya pengelolaan sampah di palangka raya

\section{KESIMPULAN}

Dari pembahasan yang telah dijelaskan, maka kesimpulan mengenai kajian pengelolaan sampah di kota palangka raya yaitu : pertama, peningkatan pengelolaan persampahan dalam skala kota palangka raya terkait dengan perlunya menyempurnakan struktur organisasi pengelolaan yang bersifat terpadu dan lintas sektoral agar terjadi peningkatan partisipasi masyarakat dan peningkatan pelayanan. Kedua, Peningkatan peran serta masyarakat yaitu perencanaan program-program yang menyangkut peningkatan peran serta masyarakat dalam penanganan persampahan di Kota Palangka Raya sebaiknya disesuaikan dengan perencanaan pola pelayanan yang terdiri dari (I) Pola penanganan skala kota (2) pola penanganan skala rumah tangga (3) pola penanganan skala kawasan.

\section{REFERENSI}

Afitah, I. 20I5. Prospek Pengembangan Wisata Danau Bulat Di Kabupaten Katingan Kalimantan Tengah. Daun: Jurnal Ilmiah Pertanian dan Kehutanan. 2(2): I-I3.

Agustino, Leo. 2012. Dasar-Dasar Kebijakan Publik. Bandung : cv. Alfabeta.

Akhmad Sudrajat. 2008. Pengertian Pendekatan, Strategi, Metode, Teknik dan Model Pembelajaran. Bandung : Sinar Baru Algensindo

Arikunto, Suharsimi. 2002. Prosedur Penelitian Suatu Pendekatan Praktik. Jakarta : Rineka Cipta.

Atmosudirdjo, Prajudi. 2005. Manajemen Dasar Pengertian dan Masalah. Malayu: Rineka Cipta.

Dwiyatmo, Kus. 2007. Pencemaran Lingkungan dan Penangannya. Yogyakarta: Citra Aji Parama.
Makmur. 2009. Teori Manajemen Stratejik Dalam Pemerintahan dan Pembangunan. Bandung: PT Rafika Aditama.

Moekijat. 2000. Kamus Manajemen. Bandumg: CV. MandarMaju

Hidayati, N., Indrayanti, A.L. 20I5. Pemanfaatan Abu Boiler Kelapa Sawit terhadap Pertumbuhan Tajuk Tanaman Tomat. Daun : Jurnal IImiah Pertanian dan Kehutanan. 2(I):54-65.

Setiadi, J. Nugroho. 2003. Konsep dan implementasi dan untuk penelitian pemasaran. Jakarta: Perdana Media.

Silalahi, Ulber. 20II. Asas-Asas Manajemen. Bandung : PT Refika Aditama 